\title{
Internationalization of Higher Education in Romania and Portugal-Strategies and Transitions at the (Semi-)Periphery
}

\author{
Ligia Deca
}

\section{Introduction}

The internationalization of higher education is, without a doubt, one of the undeniable trends that continues to (re)define governmental and university level strategies alike. In a world where knowledge is the key asset, brain circulation becomes one of the essential indicators of just how much countries and higher education institutions are willing to rethink their future moves in order to attract international students and researchers. In 2017, there were over 5.3 million international students, up from 2 million in 2000. ${ }^{1}$ The five most successful countries in attracting foreign students (in absolute numbers) were: The United States of America, the United Kingdom, Australia, France and Germany. Anglo-Saxon countries dominate this ranking, but economic development is also a powerful indicator for attractiveness. Despite the strong position of the top tier countries, some European nations, in light of the challenges posed by demography and migration, have become aware of the opportunities presented by internationalization, with a focus on attracting degree-seeking mobile students (Sin et al. 2019; Deca 2015; Mosneaga and Agergaard 2012). In fact, student mobility - both degree and credit_remains a priority as well as the most frequent activity within the internationalization agenda of European higher education institutions (Sursock 2015; EUA 2013).

This paper compares the recent history of higher education internationalization in two countries situated simultaneously at the periphery of the European Economic Area and at the semi-periphery of internationalization efforts in the university sector.

These two case studies share a recent history of transition from totalitarian regimes to functional democracy, in a wider context of accession to the European Union and the European Higher Education Area. This transition does start from different ideological standpoints (communism for Romania and fascism for Portugal) and at different points in time (1989 for Romania and 1974 for Portugal). The author will examine the internal and external drivers for internationalization of higher education

${ }^{1}$ http://data.uis.unesco.org/Index.aspx?queryid=172.

L. Deca (殴

New Europe College, Bucharest, Romania

e-mail: deca.ligia@gmail.com

(C) The Author(s) 2020

A. Curaj et al. (eds.), European Higher Education Area: Challenges for a New Decade, https://doi.org/10.1007/978-3-030-56316-5_5 
in these two national contexts, as well as how and whether their socio-economic and historical specificity influenced the way in which dominant models of internationalization have been translated at the national and institutional level.

The conclusion will include policy lessons for decision-makers and explore whether and how potential misalignments between national and institutional endeavors can pose obstacles in fulfilling strategic objectives at either level.

\section{Methodological and Conceptual Considerations}

The current article uses the empirical work done for the author's $\mathrm{PhD}$ thesis regarding the Romanian higher education system, defended in 2016 at the University of Luxembourg, as well as the interviews and research conducted in Portugal as a post-doctoral fellow at the New Europe College, in Bucharest. It is conceived as a qualitative analysis, using semi-structured interviews conducted in 2013-2015 and 2018 in both Romania and Portugal, with representative decision-makers on higher education, mainly at the national level.

The concept of periphery used in this paper is based on the Sin et al. (2019) translation of the Immanuel Wallerstein' theory of the "world system" (Wallerstein 1974), which divides countries based on the structure of their economy in: core, semi-periphery and periphery. This taxonomy was then modeled on the more niche economy of international higher education, taking as a proxy inbound/outbound mobility flows. For the purpose of this article, core countries are those that are considered net "importers" of degree-seeking students (e.g. the United States, the UK, France, Germany, the Netherlands etc.). Semi-peripheral are those countries with more balanced mobility flows, such as Poland or Portugal. And finally, those countries that are mainly "exporters" of mobile students are considered as peripheric (Romania, Bulgaria etc.).

The working assumption for this article is that peripheral and semi-peripheral countries (should) use internationalization policies that are different from those of the core countries, in light of their different circumstances, capacities and challenges (Urbanovic et al. 2016). Additionally, some of these countries, such as those situated in Central and Eastern Europe, can be considered as a 'privileged site for understanding the processes of Europeanization and internationalization' (Dakowska and Harmsen 2015: 5), using regional and international models to develop their higher education sector. Despite there being no universal model for internationalization, "a correlation exists between the standing of the higher education system in the global arena and the influence of its internationalization model worldwide." (Deca 2016: 15). In general, systems with a de facto low standing such as those in periphery or semi-periphery become net borrowers of policy practices in the realm of internationalization.

As such, countries from the periphery or semi-periphery become pertinent models in analyzing the suitability of transposing established models of internationalization to regions with different circumstances. Also, the observations made in the com- 
parison can help identify how the internationalization of higher education could be pursued without reinforcing the status-quo, namely the divisions between higher education systems worldwide (Teichler 1999), which makes more powerful actors its primary beneficiaries. De Wit et al. (2019) underline that countries with developing economies (and sometimes democracies) tend to adopt Western models of internationalization, focusing on incoming mobility, branding and prestige while also suffering from political instability. They also underline that, in such cases, other dimensions of internationalization might be more helpful in reaching the overall objectives of the higher education system (e.g. internationalization at home for enhancing overall higher education quality etc.).

\section{Romania-the Resurrection of the Internationalization of Higher Education Agenda After Three Decades of Transition}

Following its 1989 anti-communist regime Revolution, Romanian higher education and its policy framework changed according to perceived international and European trends but was also shaped by the internal imperatives of democratic transition. According to Deca (2015), each of the three decades following 1990 has constituted a distinct phase of policy change. The 1990s, for example, were a time of massification and witnessed a search for external models in order to redefine higher education in the new democratic setting. The first decade of the new millennium constituted the Europeanisation phase, heavily influenced by the Bologna Process and Romania's new EU membership. Lastly, the past decade was one in which the internationalization discourse dominated, with various highlights - rankings, international cooperation and the fight to maintain institutional capacity by attracting foreign students.

Higher education was always seen as a sign of social status in Romania. In light of its previous elitist character, the first wave of change (1990s) was linked to massification and happened in a time when other HE sectors in the world were going through similar changes. The previous technical colleges were transformed in universities and a flurry of private providers started to offset the increasing demand for a higher education degree (Damian 2011: 59). This rapid expansion of the capacity of the higher education sector came with a challenge to maintain the quality of provision, which is perhaps why Romania was the first country in Central and Eastern Europe to establish a governmental agency for quality control in this sector, in 1993-the National Council for Academic Evaluation and Accreditation (CNEEA), following a UNESCO-CEPES study with support from Japan.

There was some resistance to this push for modernization, with some actors trying to revert to the model of the pre-communist academic community. In this sense, Romania has a strong academic heritage based on the centralized Napoleonic model, combined with a second wave of centralism in higher education governance during communism (Dobbins and Knill 2009; Dobbins 2011). 
The European Union, together with the World Bank, also played an active role in redesigning the Romanian higher education landscape, which brought international trends close to those taking policy decision. A long-standing higher education expert in Romania pointed out that 'the 1990s were the decade of Euro-Atlantic influence in the Romanian higher education system. The influence of Anglo-Saxon excellence models was predominant, especially in relation to university research reform' (Interview 2).

This so-called 'Euro-Atlantic'2 influence included, for example, the introduction of moderate tuition fees and an increasing focus on research outputs inspired by the US higher education system model, as well as the adoption of British inspired models of lump sum funding (Dobbins and Knill 2009, 416). This was coupled with the introduction of EU and Bologna Process inspired recognition instruments, such as ECTS, qualification frameworks and Diploma Supplement.

At the government level, the prevailing discourse seemed to be heavily influenced at the time by the World Bank (Interview 2), whose influence started to manifest itself around 1991/1992, potentially due to its status as the main external funding source for higher education reform in this transition period (Cîrstocea 2014, 130).

The OECD also undertook a 'Review of National Policies for Education' for Romania (OECD 2000), which became highly influential amongst Romanian policy makers (Interview 1). The focus of the OECD with regard to higher education was on the system governance and structural reforms, enhancing teacher training, as well as on fostering links between universities and the labor market.

As this first phase of transition closed, international norms were largely used by the government as a form of leverage for reform in conjunction with the strong presence of international organizations on the ground, while opponents of reform did not seek to move beyond a defense of the national status quo.

In the second phase (2000-2008), there seems to be an instrumentalization of the Bologna Process by the government in the context of the EU accession process, mostly looking at the structure of the higher education system and mainly using a negative legitimation strategy (i.e. invoking the perils of choosing a different path for the upcoming accession of Romania to the EU). In this phase, the government had the perhaps surprising help of one of the student national federations (ANOSR), which used the Bologna Process in a positive way, as a resource to establish itself and to promote student interests.

In the third phase (2008-2019), the government promoted a policy shift based on the need to increase Romania's international competitiveness in the discussions surrounding the National Law on Education (Law 1/2011), but other actors in higher education diversified their counter-arguments by including international references (such as the use of the Bologna Process for arguing in favor of maintaining a collegial system of higher education by students and academic staff representatives). In this

\footnotetext{
2 Euro-Atlantic is a term used to capture the desire of the Romanian policy makers to become compatible with both EU and US norms, broadly seen as 'Western' influences. The Romanian efforts towards both EU and NATO integration at the time is also an influencing factor in this regard.
} 
timeframe, Romania also assumed the Secretariat of the Bologna Process (20102012) and organized the EHEA Ministerial Conference and Bologna Policy Forum in 2012. As an EHEA Vice-Chairing country, Romania was an influential player in the drafting of the EHEA Bucharest Communique.

Over these three successive moments, there is a clear evolution of the use of international norms by Romanian higher education actors. During the 1990s, the system and its actors were in search of relevant models and still heavily centralized. In the second 'Bologna' phase, we can already see two interesting instances of strategic use of international norms. On the one hand, the government used the Bologna Process both as a resource for its reform and as a constraint to limit opposition. In the third phase, we witness the government using international processes to legitimize national reforms but also starting to 'upload' national policy priorities within the areas where it played a significant role, such as the EHEA. Also, at this moment, actors displayed a diversified use of internationally inspired arguments for their policy positions, notably in the defense of the principle of stakeholder consultation itself.

In the Romanian case, according to Deca (2016: 130), "internationalization was initially a wider concept, including mediation by the Government of international policy processes in support for domestic reform, but also a way to ensure 'belonging' in the European community. In recent years, internationalization evolved towards an independent policy area, in connection with the desire to increase economic competitiveness in a knowledge-based society."

At the same time, internationalization of higher education as a policy process has resurfaced in the past decade as a central concern for universities, after a relative lack of attention in the 1990-2010 timeframe. In the 1980s, Romania was among the top 15 countries worldwide in terms of attracting foreign students (10\% of the total student number) due to the strategies employed by the communist government, which included special student support services, lowering tuition fees, providing government scholarships for priority countries etc (Pricopie and Nicolescu 2011).

In light of the decreasing number of foreign students starting with the late 1980s and continuing towards year 2000, Romania decided to increase its competitiveness and align its higher education system structure with the perceived "European model", which meant adopting the Bologna Process structures (three cycles, ECTS, Diploma Supplement, QF) between 2004-2007 (Deca et al. 2015). Following the adoption of Law 1/2011, a growing concern for internationalization as a distinct policy endeavor was evident at both national and institutional level, perhaps augmented by the rankings shock.

As previously noted, international organizations were key actors in promoting internationalization either via technical/ financial assistance or through thematic reports. Also, the support of specialized agencies was essential. One such example is the Executive Agency for Higher Education, Research, Development and Innovation Funding (UEFISCDI), who developed and implemented the 'Internationalization, equity and university management for quality higher education in Romania' (IEMU) project, in 2014-2015, in partnership with the International Association of Universities (IAU) and the National University of Political Studies and Public Administration (SNSPA). This project produced a strategic framework for interna- 
tionalization, helped twenty Romanian universities to develop their own strategic plans for internationalization and created the "Study in Romania" portal. Another valuable deliverable was a Blueprint for developing a structure for the promotion of Romanian higher education abroad. However, these documents never translated into a nationally endorsed policy. One obstacle for internationalization policies to overcome their current ad-hoc and fragmented status is the legal and political instability. The fast-paced change in ministers poses real challenges to designing a coherent national policy for higher education in general and for internationalization of higher education in particular. Also, the lack of national investment in internationalization could not be fully offset by European programs, even though some European calls prompted the Education Ministry to provide matching funding (e.g. the European Universities Initiative call).

Despite the discursive prioritization of internationalization of higher education (Government of Romania 2019), the internationalization of higher education as a distinct policy never reached policy formulation phase. The relative lack of alignment between general higher education (and general education) policy, internationalization and other policy areas (immigration, foreign policy, economic policy) also impinges on materialising a national approach. It is clear that without a clearly formulated national policy, which would include responsibilities, priorities, targets and financial allocations, no significant progress can be made or measured in areas such as mobility, cross-border higher education provision or even internationalization at home. (Deca 2016)

\section{Portugal-How a Former Empire Strikes Below Its Weight}

The Portuguese higher education system has its roots in the Middle Ages, with the first higher education institution being set up in Lisbon, later moving to the city of Coimbra-University of Coimbra (1290). Its evolution was later influenced by the needs of the Portuguese Empire, with engineering and medical higher education institutions being set up in various colonies (South-America, Asia etc.), in order to support the needs of those societies. The links between the former Portuguese Empire territories and the Portuguese universities are very relevant still when looking at how internationalization of higher education is conceptualized in national and university level strategic documents. The establishment of the Community of Portuguesespeaking Countries (Comunidade de Países de Língua Portuguesa-CPLP) in 1996 was an added driver to the existing intense academic links with these territories.

Mobility statistics prove that Portugal welcomes more than $60 \%$ of its international students from its former territories: Brazil, Angola, Cape Verde, Mozambique, São Tomé and Príncipe, Guinea Bissau and East Timor. All countries except Brazil and East Timor gained their independence in the 1970s, almost at the same time with the Carnation Revolution, which makes Portugal a particular case of a transitioning 
country, as the country retained close and multi-faceted links with a number of emerging new states. The Portuguese government materialized its interest in maintaining its influence in these territories by offering scholarships to prospective students from CPLP countries (Veiga et al. 2006). In addition, there was another driver to increased mobility from these countries - the lack of capacity of higher education systems in these countries - which became a real push factor for students to seek tertiary education in Portugal (França et al. 2018).

With the incentive of the increased demand for higher education, in the 1980s and 1990s, a flurry of private higher education institutions tried to offset the two trends - the democratization of higher education in Portugal and the intake from former colonies. At the same time, culturally and historically, CPLP students were not seen as "foreign", even in the legal sense, since universities could not impose extra fees and with special quotas allotted for their enrolment in Portuguese universities.

In this context, Law 62/2007 which addressed the Juridical Regime of Higher Education acted on two fronts-enacted new provisions related to quality assurance and provided the opportunity for higher education institutions to change their legal regime in order to become autonomous foundations, with an increased level of institutional autonomy. Interestingly, only three higher education institutions opted for this possibility at the time - the University of Porto (the largest institution in Portugal by number of students at the time), ISCTE Lisbon and the University of Aveiro. Other higher education institutions later chose the same path-University of Minho, Nova University etc.

The financial crisis in 2008/2009 hit in a dramatic way the Portuguese economy, with drastic cuts to the higher education sector (Teixeira 2012). In addition, this prompted increased levels of labor migration, coupled with declining demographic trends. In this context, Portuguese universities were desperate to find ways to increase their revenues (Sin et al. 2016) and attracting foreign students was seen as one such avenue.

In February 2014, the Portuguese Ministry of Education and Science and the Ministry for Regional Development joined forces in order to develop a strategy for the internationalization of Portuguese higher education (MADR/MEC 2014). In July 2015, the Portuguese Government adopted this strategy (Council of Ministers Resolution 47/2015). This document provided guidance and political priorities in what was an area of interest for most, if not all, higher education institutions in Portugal. The strategy included provisions for the promotion of the national higher education system and its institutions (universities and polytechnics) abroad. It also designated priority regions for further cooperation, going beyond EU and CPLP countries. It aimed to improve the provision of information for prospective international students and to remove some of the red tape associated with visas, residence, financial operations, etc. This was partially achieved by creating the 'via verde' - a fast way-for the admission of international candidates in Portuguese higher education institutions and for their settling in the country. Lastly, the strategy aimed to augment the number of higher education programmes offered in English.

Responding to a similar demand for clarifying the national framework for internationalization of higher education, in the same year-2014, the Statute of the Interna- 
tional Student (Decree-Law 36/2014) was adopted. This piece of legislation defines international students as those originating from other countries than the EU/EEA members. The main objective of the law is to define a new admission regime for students that can be treated differently compared to national students, according to EU law. More autonomy was thus given to higher education institutions in setting admission practices for international students, as well as for establishing tuition fees that reflect the actual costs of higher education. As an exception, students from CPLP countries could benefit from a special scholarship, in order to maintain the links with former Portuguese Empire territories (with the exception of Brazil). However, this last provision is not yet implemented (França et al. 2018).

If prior to the 2014 Student Statute, students coming from Portuguese speaking countries were not differentiated from national or EU/ EEA students when it came to tuition fees, the change in strategy has incentivized public higher education institutions to be interested in attracting more international students, similarly to private universities, especially in light of the dwindling numbers of national candidates (Sin et al. 2016: 185-186). Mainardes et al. (2012) point to an increasing tendency to look at internationalization of higher education in Portugal with a market logic, which is also signaled by the internationalization commission of the representative body of Portuguese public universities (CRUP): 'There is a mentality to change and an idea to bear in mind: higher education is exportable' (Assunção 2017: 7).

In this light, several initiatives were put in motion: one coordinated by CRUP'Universities Portugal' - with the support of the Government, the Camões Institute, the Portuguese Agency for Foreign Investment and Trade, the Ministry of Foreign Affairs, etc. (Assunção 2017); another one planned by polytechnic institutions for joint promotion abroad (Mourato 2016) and a very recent one in 2019- studyresearch.pt. The latter is in line with the 2016 Decree which emphasized the link between higher education and research for further internationalization efforts and encompassed the previous "Study in Portugal" portal. A clear focus of the Portuguese Government was attracting Portuguese researchers back to Portugal by offering $50 \%$ tax deductions to those deciding to relocate back in the country. Finally, in 2019, 2500 more places for international students were awarded by the Portuguese Government to higher education institutions, in order to enhance their capacity to attract feepaying students.

However, despite efforts made in the past decade to raise the profile of Portuguese higher education institutions, the OECD was critical of the strategic endeavors in its Review of Portuguese Higher Education report (OECD 2019). Even if separate initiatives exist, there is little coherence between them, as well as between higher education, research and innovation policies. In terms of percentages of the overall student body in Portugal, foreign students represented around 6\%, with $4 \%$ of all bachelor students being international, as well as $8 \%$ of all Master students and $27 \%$ of PhD students. ${ }^{3}$

Similar to other countries, the strategy for the internationalization of higher education (and research, to some extent) in Portugal is linked with the country's foreign

\footnotetext{
${ }^{3}$ https://www.oecd.org/education/education-at-a-glance/EAG2019_CN_PRT.pdf.
} 
policy interests. In this case, it attempts to consolidate the role of Portugal as an education and science hub for Portuguese speaking communities across the world, while relying on the brain gain phenomenon that might be boosted by the country's EU membership. Indeed, Portugal frequently refers to itself as a gateway to Europe (Almeida 2008). A special interest is seen in relation to the Chinese market of potential degree-seeking students, as Portuguese is the language of several African and Asian countries in which China currently shows clear economic and strategic interest (e.g. Angola, Macao etc.). One prominent former Portuguese expert underlined the win-win strategy that Portugal and Chinese authorities pursue in this respect-China sends students to Portugal in order to have a European higher education degree and to learn Portuguese and then deploys these graduates in Portuguese speaking countries, in order to make sure it has the human resource to further its interests there; Portugal, in turn, gains both fee-paying students and well-placed graduates that speak Portuguese (Interview 3).

Portugal's internationalization efforts are declaratively in line with its main foreign policy goals. However, the oversized focus on attracting degree-seeking students and its lack of continuity in following its strategic policy documents (mainly due to political and economic changes) makes this former empire strike well below its weight in terms of higher education internationalization (Interview 4). Despite its strengths, it displays a similar tendency to imitate models of internationalization characteristic to economically developed countries, while not fully taking advantage of its unique strengths in the global setting.

\section{Comparative Analysis and Conclusive Remarks}

Portugal and Romania navigated a historically recent transition from totalitarian regimes to democracy (from the Salazar and Ceausescu regimes respectively). They are both EU members and have been heavily influenced by efforts to harmonize higher education systems in Europe. And they have definitely been impacted by worldwide transformations, such as the 2008/2009 financial crisis or the post-2010 rankings shock. As such, internationalization of higher education has definitely been, in the case of Romania and Portugal, a "driver for policy change" (Enders 2004).

In general terms, in the Romanian case, internationalization did not yet reach the stage of policy formulation at the national level, despite commendable efforts made in the IEMU project, where a strategic framework for internationalization was developed, together with the "Study in Romania" portal and with 20 university strategies for internationalization. Portugal is ahead in terms of national level policy formulation, with a framework developed and adopted by the Council of Ministers in 2015 and subsequently adapted and developed. However, political instability affected a concrete translation of this strategy in a monitored work-plan, especially since no targeted funding was provided for its implementation.

A similar push for internationalization in the two countries was generated by internal structural drivers: rural/urban (Romania) versus coastal/inland (Portugal) divides, 
resource scarcity due to decreasing public investment and demographic downturn, as well as a noticeable impact generated by the 2009/2009 financial crisis. However, different academic traditions and history may have had an impact on the potential for internationalization at the institutional level. The oldest university in Portugal, the University of Coimbra was founded in 1290, while the oldest university in Romania, the University of Iasi was set-up in 1860. Since those moments, the development of the two countries in terms of geographical spread, political influence and economic prowess influenced the ability to attract and retain both national and foreign students. Both countries have a large number of their foreign students coming from territories in which Portuguese and Romanian are spoken, which has something to say about the influence of foreign policy and of language proficiency of the academia over internationalization policies. Also, in the early 2000s, both countries were heavily influenced by the structural changes of the Bologna Process and the EU policies (modernization of higher education agenda, Erasmus and Erasmus+, research cooperation etc.).

Despite their different historical evolution, many traits are common to the two countries, which share their relative peripheric position in the global internationalization of higher education arena. Firstly, both systems retain numerous obstacles related to administrative red tape, foreign language barriers (especially at the level of administrative and teaching staff), financial support for internationalization, internal resistance. Importantly, the non-alignment of discourse and action is very present in the perception of the university leadership (e.g. in terms of immigration proceduresdespite a formal focus on attracting international students, the number of student visa requests being refused is still high in areas declared as important recruitment markets).

A key role of individual policy entrepreneurs can be observed in both cases, especially when talking about the actors who pushed the internationalization agenda ahead. They were generally educated abroad via programs such as Fulbright, socialized in European structures and have changed multiple hats, from rectors to decisionmakers and from NGO leaders to ministers. Historical links remain of great significance for the two countries, with clear national policies favoring academic links and inward mobility related with territories in which the same language is spoken or that were in the same political alliance at some point in time (Moldova and east of the Iron Curtain for Romania and the CPLP countries for Portugal).

Despite their different trajectory and the diverse points in time when the transition from autocratic regimes to democracy began, as well as despite the different availability of EU funds for higher education projects (due to different EU accession years), Romania and Portugal share similar selling points when marketing HEIs or the entire national higher education system abroad. These include EU membership, safety, quality of life, low cost of living, tourist attractions/ lifestyle, with the extra language highlight for Portugal. This can be interpreted as a sign of the emergence of a European brand for higher education marketing, despite modest pan-European efforts in this sense.

There is an interesting comparison to be made regarding the way in which the diffusion of international norms happens in the context of transitions from differ- 
ent ideological totalitarian regimes. A neo-liberal and marketization logic is quite common in the way in which internationalization of higher education is perceived and even mainstreamed in various higher education systems. Romania and Portugal are no exception, and the race for more international, fee-paying students and for a better place in international rankings is a clear indication. This shows that there is less current ideological underpinning of internationalization efforts than it could have been expected, in light of the distinct history of the two countries.

However, there is a discussion to be had regarding the usefulness of using "big player" tactics when a higher education system is in fact more suited for a "niche" strategy for internationalization. Trying to attract as many international degreeseeking students as possible in order to boost your international standing and to offset the depleted university budget is perhaps not the best strategy, especially if the overall goal of the higher education system is to help in reducing regional divides or to offset shortages in key sectors such as health. Furthermore, in terms of higher education marketing, it is clear that not all countries can or should successfully target China or South-East Asia since strong links between higher education systems are hard to build and promising when they already exist.

To sum up, both Romania and Portugal have been making recent efforts to boost the international profile of their higher education systems and institutions. State and university efforts seem to converge, and the drivers that push the internationalization agenda are less different than what could have been expected from the experience of countries with a more visible profile in the global higher education market. With this in mind, more attention could be paid to what constitutes a national internationalization strategy and whether all types of higher education systems actually need a coordinated internationalization effort in order to support university efforts.

\section{Interviews}

Interview 1: Ministry official in Romania 1998-2000, conducted on 29.03.2013.

Interview 2: Ministry official 1991-1992 in Romania, member of the Presidential Commission on Education and Romanian BFUG representative, conducted on 03.04.2013

Interview 3: Quality assurance agency official in Portugal, conducted on 14.06.2019

Interview 4: Adviser to the President on Education and Research in Portugal, conducted on 12.06.2019. 


\section{References}

Almeida, M. V. (2008). O Complexo Colonial Português. Jornal Hoje Macau October 31, 10-11. Assunção, M. (2017). Exportação do Ensino Superior. In PortugalGlobal: A crescent internacionalização do ensino superior português (pp. 7-8). Lisboa: AICEP.

Cîrstocea, I. (2014). Les restructurations de l'enseignement superieur en Roumanie apres 1990 Apprentissage international de la gestion, professionnalisation de l'expertise et politisation de l'enjeu universitaire. Revue d'etudes comparatives Est-Ouest, 45(1), 125-163.

Dakowska, D. \& Harmsen, R. (2015). Laboratories of reform? The Europeanization and internationalization of higher education in Central and Eastern Europe. European Journal of Higher Education, 5(1), 4-17.

Damian, R. (2011). The Bologna Process as a Reform Initiative in Higher Education in the Balkan Countries. European Education, 43(3), 56-69.

de Wit, H., Rumbley, L., Craciun, D., Mihut, G., \& Woldegiyorgis, A. (2019). International Mapping of National Tertiary Education Internationalization Strategies and Plans (NTEISPs). Chestnut Hill: CIHE Boston College

Deca, L. (2015). International norms in the reform of Romanian higher education: a discursive analysis', European Journal of Higher Education, 5(1), 34-48. https://doi.org/10.1080/21568235. 2014.971040

Deca L., Egron-Polak E., \& Fiţ C.R. (2015) Internationalisation of Higher Education in Romanian National and Institutional Contexts. In: Curaj A., Deca L., Egron-Polak E., \& Salmi J. (Eds.), Higher Education Reforms in Romania. Cham: Springer.

Deca, L. (2016). Understanding the Internationalization of Higher Education as a Policy Process. The case of Romania. $\mathrm{PhD}$ thesis, University of Luxembourg, available at: https://orbilu.uni.lu/ handle/10993/31206

Dobbins, M. (2011). Explaining different pathways in higher education policy in Romania and the Czech Republic. Comparative Education, 47(2), 223-245.

Dobbins, M. \& Knill, C. (2009). Higher Education Policies in Central and Eastern Europe: Convergence toward a Common Model?. Governance, 22(3), 397-430.

Enders, J. (2004). Higher education, internationalisation, and the nation-state: Recent developments and challenges to governance theory. Higher Education, 47(3), 361-382.

European University Association (2013). Internationalisation in European higher education: European policies, institutional strategies and EUA support, Brussels: EUA.

França, T., Alves, E \& Padilla, B. (2018). Portuguese policies fostering international student mobility: a colonial legacy or a new strategy? Globalisation, Societies and Education, 6(3), 325-338.

Government of Romania (2019). Governing Programme, available at https://gov.ro/ro/obiective/ programul-de-guvernare (last accessed on 01.04.2020)

MADR/MEC (2014). Uma estratégia para a internacionalização do ensino superior português [A strategy for the internationalisation of Portuguese Higher Education]. Lisbon: Ministry of Regional Development and Ministry of Education.

Mainardes, E. W., Alves, H., Raposo, M., \& de Souza Domingues, M. J. C. (2012). Marketing in higher education: A comparative analysis of the Brazil and Portuguese cases. International Review on Public and Nonprofit Marketing, 9(1), 43-63.

Mosneaga, A. \& Agergaard, J. (2012) Agents of internationalisation? Danish universities' practices for attracting international students. Globalisation, Societies and Education 10(4), 519-538.

Mourato, J. (2016). Ensino Superior Politécnico \&amp; internacionalização', Público, 23 February. OECD (2000). Reviews of National Policies for Education: Romania 2000, OECD Publishing, https://doi.org/10.1787/9789264181731-en

OECD (2019). OECD Review of Higher Education, Research and Innovation: Portugal, OECD Publishing, Paris. https://doi.org/10.1787/9789264308138-en

Pricopie, R. \& Nicolescu, L. (2011). Analiza diagnostic. Universităile în contextul europeniz globalizării [online] UEFISCDI. Available at: http://www.edu2025.uefiscdi.ro/UserFiles/File/ LivrabileR1/Analiza\%20diagnostic\%20Panel\%205\%20V5\%20revised\%2011\%20nov..pdf 
Sin, C., Antonowicz, D. \& Wiers-Jenssen, J. (2019). Attracting International Students to Semiperipheral Countries: A Comparative Study of Norway, Poland and Portugal. High Educ Policy. https://doi.org/10.1057/s41307-019-00135-3

Sin, C., Veiga, A. \& Amaral A. (2016). European Policy Implementation and Higher Education:Analysing the Bologna Process. London: Palgrave.

Sursock, A. (2015). Trends 2015: Learning and Teaching in European Universities. Brussels: EUA.

Teichler, U. (1999). Internationalisation as a challenge for higher education in Europe. Tertiary Education and Management, 5(1), 5-23.

Teixeira, P. (2012). The changing public-private mix in higher education: Analysing Portugal's apparent exceptionalism. In G. Neave and A. Amaral (Eds), Higher education in Portugal 19742009. A nation, a generation (pp. 307-328). Dordrecht: Springer.

Wallerstein, I.M. (1974). The modern world-system. New York: Academic Press.

Urbanovic, J., Wilkins, S., \& Huisman, J. (2016). Issues and challenges for small countries in attracting and hosting international students: the case of Lithuani. Studies in Higher Education, 41(3), 491-507.

Veiga, A., Rosa, M. \& Amaral, A. (2006). The internationalisation of Portuguese higher education: how are higher education institutions facing this challenge? Higher Education Management, $18(1), 113-28$.

Open Access This chapter is licensed under the terms of the Creative Commons Attribution 4.0 International License (http://creativecommons.org/licenses/by/4.0/), which permits use, sharing, adaptation, distribution and reproduction in any medium or format, as long as you give appropriate credit to the original author(s) and the source, provide a link to the Creative Commons license and indicate if changes were made.

The images or other third party material in this chapter are included in the chapter's Creative Commons license, unless indicated otherwise in a credit line to the material. If material is not included in the chapter's Creative Commons license and your intended use is not permitted by statutory regulation or exceeds the permitted use, you will need to obtain permission directly from the copyright holder.

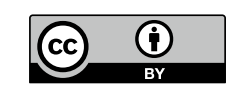

